\title{
WATER QUALITY OF SUNDARIJAL RESERVIOR AND ITS FEEDING STREAMS IN KATHMANDU
}

\author{
Krishna R. Bhattarai*, Bharat B. Shrestha** and Hari D. Lekhak** \\ *Birendra Sainik Awasiya Mahavidyalaya, Bhaktapur, Nepal. \\ **Central Department of Botany, Tribhuvan University, Kathmandu, Nepal.
}

\begin{abstract}
Physico-chemical ( $\mathrm{pH}$, conductivity, dissolved oxygen, alkalinity, hardness, nitrogen, heavy metal, etc) and bacteriological (coliform bacteria) characteristics of water were studied in samples collected from Sundarijal reservoir and its main feeding streams: Bagmati, Nagmati and Shyalmati in 2003 and 2004 AD. Human activities near the water bodies and sanitary condition of the residential areas of watershed were also examined. Although public awareness and proper management of watershed and reservoir premises were lacking, yet the physico-chemical characters were within the standard of World Health Organization (WHO) and European Commission (EC) for drinking water. However, the coliform bacteria were high and water was not safe to consume without intense treatments with disinfectants.
\end{abstract}

Key words: Coliform; Heavy metals; Human activities; Physico-chemical characters; Sanitary condition.

\section{INTRODUCTION}

Water is the most vital resource for all kinds of life on this planet and essential for ensuring the integrity and sustainability of the earth's ecosystems (UNESCO, 2003). Rapid population growth, increasing living standards in urban areas and industrialization have resulted in greater demand of quality water on one hand, while on the other hand, pollution of water sources is increasing steadily. In the recent years, the availability and access to fresh water have been among the most critical natural resource issues in the world. Freshwater is essential to human health, agriculture, industry and natural ecosystems, but is now running scarce in many regions of the world (WWF, 1998). Water is most obviously related to the issue of social development through its impacts on health. Much of the health problems in the underdeveloped and developing countries are largely due to lack of adequate amount of safe drinking water. There can be no satisfactory state of community health and well being without safe water supply (Park 1994, UNESCO, 2003).

Any chemical, biological or physical change in water quality that has a harmful effect on living organisms or makes water unsuitable for desired use is water pollution (Miller, 2002). It is one of the most important problems being faced by both developed and developing countries as a major cause of human disease, misery and death. WHO (1991) has estimated that some 30,000 people die every day from water related disease and this kind of episode is more critical in the less developed countries, where up to $80 \%$ of the illness is water related. Due to lack of potable water and proper sanitation, over 15 millions children below five years die each year (UNICEF, 1997). In Nepal, more than 33,000 people die every year by gastro-enteritis caused by drinking water contamination and poor sanitation (Anonymous, 2004). Surface water and ground water are the major natural sources of water supply in majority of cities of Nepal, including Kathmandu valley, the capital city of Nepal. In general, surface water possess a high possibility of organic, bacterial and viral contamination (Joshi et al., 2000) and its quality depends on land use pattern of watershed, agriculture practices such as use of agro-chemicals, and sanitary situation of inhabitants. The drinking water quality in Kathmandu valley is very unsatisfactory. While considering microbiological water quality, even chlorinated water of Kathmandu is found heavily contaminated with faecal materials (Jha and Lekhak, 1999). Over $80 \%$ of drinking water contains very high count of bacteria. In this paper we have reported physico-chemical and microbiological characteristics of water samples collected from Sundarijal Reservoir and its main feeding streams. It is one of the major sources of water supply to Kathmandu valley.

\section{MATERIALS AND METHODS}

\section{Study Area}

Sundarijal reservoir $\left(27^{\circ} 47^{\prime} \mathrm{N}, 8^{\circ} 20^{\prime} \mathrm{E}, 1576 \mathrm{~m}\right.$ asl $)$ lies on the north-eastern part of Shivapuri National Park. The climate is sub-tropical with average maximum temperature $24^{\circ} \mathrm{C}$ in May and minimum $3.5^{\circ} \mathrm{C}$ in January. Average annual precipitation is $2586 \mathrm{~mm}$, with heavy monsoon rainfall between June and September which accounts about $85 \%$ of total precipitation (Department of Hydrology and Meteorology, Kakani Weather station, 1994-2003AD.) Most of the area surrounding the reservoir is covered by sub-tropical to temperate forests with the exception of agricultural lands and settlements of Mulkharka and Okhreni Village Development Committees (VDC), which constitutes about 8\% of the total catchments (ENPHO 1996).

Author for Correspondence: Krishna R. Bhattarai, Birendra Sainik Awasiya Mahavidyalaya, Bhaktapur, Nepal. Email: krbhattarai@gmail.com 
The important tree species of the surrounding forest are: Alnus nepalensis, Prunus cerasoides, Quercus glauca, Pinus roxburghii, Quercus semecarpifolia, Rhododendron arboreum, Lyonia ovalifolia and Myrica esculenta (DNPWC, 2003). The feeding streams of the reservoir are Bagmati, Nagmati and Shyalmati, which have different catchments areas. The catchments of Bagmati are Bagdwar area and adjacent villages like Okhreni, Chlilaune and Kune gaun; the catchments of Nagmati are Mulkharka and the adjacent forests whereas the catchments of Shyalmati have forests only and not the settlement areas.

The human settlements (Mulkharka and Okhreni VDCs) are located at two kilometers above the Sundarijal reservoir. The inhabitants are Tamang with more than one thousand population. The villages are unhygienic and people seemed to be unaware about the effects of water pollution. The reservoir premise was frequently used for cattle grazing, as well as for cooking food by trekkers, for taking bath and washing.

\section{Questionnaire Survey}

During every field visit any human and human related activities that affect water quality around the reservoir and other streams were closely observed. Questionnaire survey was carried out on $4^{\text {th }}$ May 2004 in Okhreni village, and on $8^{\text {th }}$ May, 2004 in Mulkharka village. Questionnaire survey was carried to seek information about the cultivation practices, use of biocides, management of wastes, collection of forest resources, etc or which may have direct or indirect impact on water quality parameters.

\section{Water Sample Collection}

To determine the water quality and limnological parameters, water samples were collected in mid-monsoon ( $8^{\text {th }}$ August, 2003), winter ( $2^{\text {nd }}$ December, 2003) and pre-monsoon (27 ${ }^{\text {th }}$ April, 2004) seasons. Three water samples were collected from each of the four sites: (i) Sundarijal reservoir, near outlets to treatment plant, (ii) Nagmati Khola, (iii) Bagmati Khola, and (iv) Shyhalmati Khola. Water samples from the streams were collected at a distance of $10-15 \mathrm{~m}$ from the reservoir. Water samples were collected in clean plastic bottles at mid day (11.00 AM - 12:30 PM). The samples were collected from surface in Bagmati, Nagmati and Shyalmati whereas in the reservoir they were collected at $30 \mathrm{~cm}$ depth from the surface. For microbiological analysis, the samples were collected in sterilized bottles. For heavy metal analysis, each $500 \mathrm{ml}$ samples were acidified with $2 \mathrm{ml}$ conc. $\mathrm{H}_{2} \mathrm{SO}_{4}$ on the spot. The water temperature of each site was measured on the spot with mercury thermometer.

\section{Laboratory Analysis}

\section{Physical and Chemical Properties}

Dissolved oxygen (DO), pH and conductivity were determined within three to four hours of collection in Nepal Bureau of Standards and Metrology (NBSM) laboratory, Balaju. Other parameters like chemical oxygen demand (COD), total dissolved salts (TDS), nitrogen (N), phosphorous (P), heavy metals, microbiological analysis were also carried out at NBSM labo- ratory. Analysis of water hardness, alkalinity and algal enumeration was done at the Central Department of Botany, Tribhuvan University, Kirtipur. All the samples were stored in refrigerator at $4^{\circ} \mathrm{C}$ before analysis.

Electric conductivity was measured by conductivity meter (inoLab Cond Level L. WTW) and pH by pH meter (692 pH/ Ion Meter). Total dissolved solids was measured by evaporation method; dissolved oxygen (mg/l) by Winkler's method; total nitrogen by micro-Kjeldahl method; and phosphorus by spectrophotometirc method (model: Spectronic 21D MILTON ROY). All these methods have been described in APHA (1992). Total alkalinity (mg/l) and total hardness (mg/ l) were measured following Saxena (1989), and chemical oxygen demand (mg/l) following Gupta (2000). Heavy metals (Fe, Mn, $\mathrm{Cr}, \mathrm{Cu}, \mathrm{Zn}$ and $\mathrm{Pb}$ ) concentrations were directly measured in the Atomic Absorption Spectrophotometer (AAS, PERKINELMER 2380) where a sample was aspirated into a flame and atomized. Amount of specific monochromatic light absorbed by the atomized element was measured which was calibrated to give the concentration of the element directly.

\section{Bacterial Analysis}

Both, the total coliforms (TC) and faecal coliforms (FC) were enumerated by membrane filtration (MF) procedure. Culture and enumeration were done following the methods of FAO (1979) and APHA (1992). All the samples were analyzed one day after their collection. For total coliforms (TC), Whatman sterile filter paper of pore size $0.45 \mathrm{~m}$ was used to filter $100 \mathrm{ml}$ water sample. Then, the filter paper was placed on sterilized plate containing $2 \mathrm{ml}$ M-ENDO BROTH (Millipore, M00000P2E) as media spreaded on media pad (Whatman). For each sample, triplicate sets were prepared and were incubated at $35^{\circ} \mathrm{C}$ for $24 \mathrm{~h}$. For faecal coliform (FC), Millipore sterile filter paper of pore size $0.7 \mu \mathrm{m}$ was used to filter $100 \mathrm{ml}$ of the sample. Then, the filter paper was placed on sterilized plate containing $2 \mathrm{ml} \mathrm{M-FC} \mathrm{medium} \mathrm{(Millipore,} \mathrm{M00000P2F)}$ as media spreaded on media pad (Millipore, $47 \mathrm{~mm}$ ). Here also, triplicate sets were prepared for each sample and incubated at $45^{\circ} \mathrm{C}$ for $24 \mathrm{~h}$. Each negative plate was further incubated for $24 \mathrm{~h}$.

After the presumptive test, confirmatory test was done for each positive plate for total coliform and faecal coliform on media of Phenol Red Lactose Broth (HIMEDIA). The media was sterilized in autoclave and a loop-full of each positive plate content was transformed into each test-tube with media containing one Durham's vial in inverted position. For the confirmatory test of total coliform, the test-tubes were incubated at $35^{\circ} \mathrm{C}$ for $24 \mathrm{~h}$ and for the confirmatory test of faecal coliform, the test-tubes were incubated at $45^{\circ} \mathrm{C}$ for $24 \mathrm{~h}$.

\section{RESULTS AND DISCUSSION}

\section{State of Environment}

The inhabitants of Mulkharka and Okhreni VDCs were mostly Tamangs with more than one thousand population in 321 households, and were less educated. About $85 \%$ of the households used tap water for drinking and remaining households 


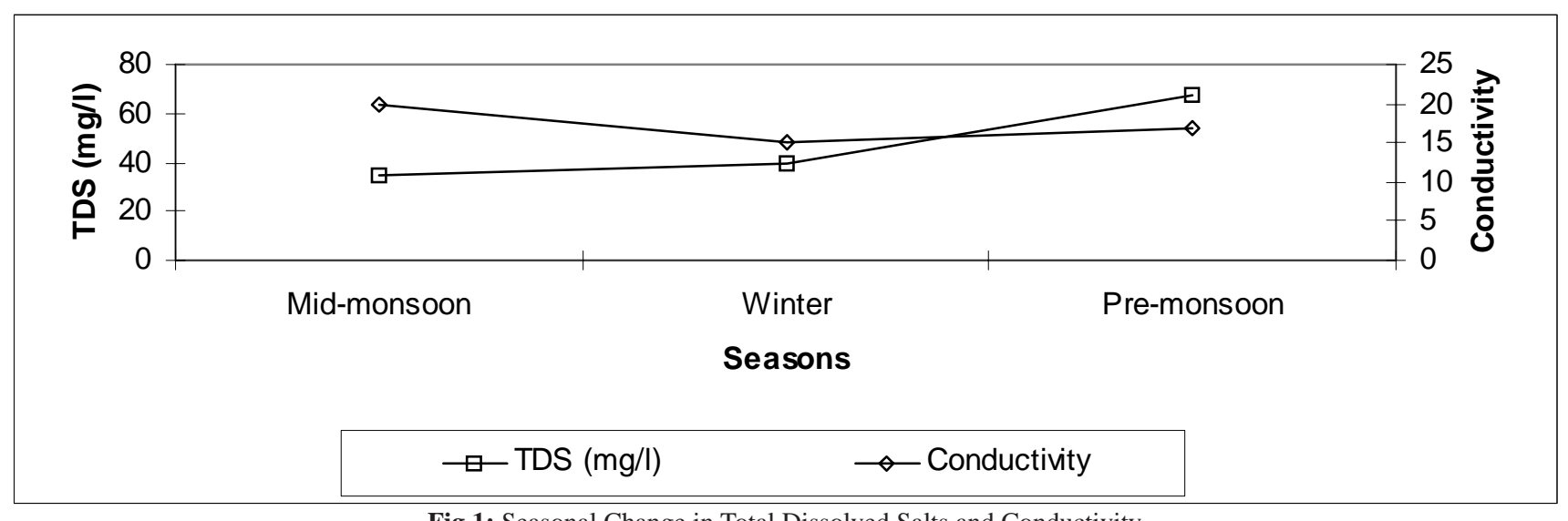

Fig 1: Seasonal Change in Total Dissolved Salts and Conductivity

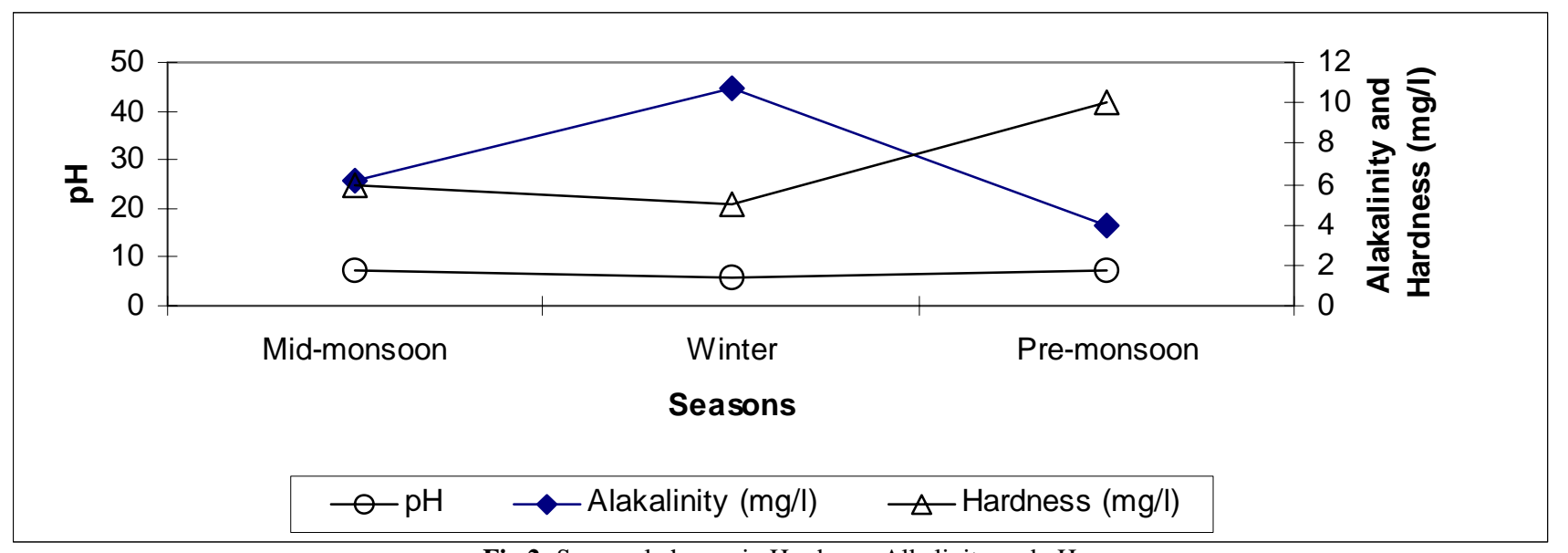

Fig 2: Seasonal change in Hardness, Alkalinity and $\mathrm{pH}$

used nearby streams. Only 40\% of households had managed latrine but only $30 \%$ of them were sanitary type with septic tank. In rainy season the excreta from open toilets of these villages flowed down and mixed with reservoir's water. Most of the households (95\%) disposed solid wastes in open areas. In general the residential area in the catchments was unhygienic which could be responsible for high TC and FC count in the water bodies of Sundarijal area (ENPHO 1996, 1997, also see bacterial contamination below).

The main occupation of the settlements is farming, animal husbandry as well as making alcoholic drinks. They used pesticides and chemical fertilizers along with compost in their agricultural land. The fallow season was found November to February/March in each year. People practice both free grazing and stall feeding to their cattle. Since free cattle grazing in watershed could pollute water (ENPHO, 1997) stall feeding could help to improve water quality. Forest was the main source of fire-wood, timber, fodder and litter. About $97 \%$ of the households depended only upon firewood for cooking and other heating purposes. Though the picnic spot was far from the reservoir, visitors and trekkers using reservoir premises for picnic, recreation, cooking, bathing and washing were observed during our field visit. Animal grazing was also found on the reservoir premises. In general the watershed area was not managed properly and being environmentally degraded. Immediate effort is necessary to improve environment of Sundarijal watershed for continuous supply of safe drinking water to the capital city.

During the study, it was found that $70 \%$ respondents were not aware of the need of watershed conservation. Though the catchment area lies within Shivapuri National Park, there was lack of effective organizational involvement in the protection and sustainable management of natural resources. All the respondents informed that in past few years there was no activity and program of National Park for watershed conservation. A people centered, demand-driven, integrated and participatory approach is the only key to successful development of watershed management in Nepal. Watershed management of the present study sites is of great importance to ensure continuous availability of water for drinking, electricity generation, irrigation and recreation. Watershed management with ecosystem approach could increase production, both from agriculture and forests, improve economic conditions by promoting income generating activities and generating employment activities and ameliorating environmental conditions.

\section{Physico-chemical Characters}

Water temperature was highest during mid monsoon and lowest during winter similar to the previous report for the same water body (Paudyal 2001, ENPHO 1997). Such changes in water temperature was found to be related with corresponding changes in atmospheric temperature (Kundangar et al., 1996). The average temperature of water in all the sites was 


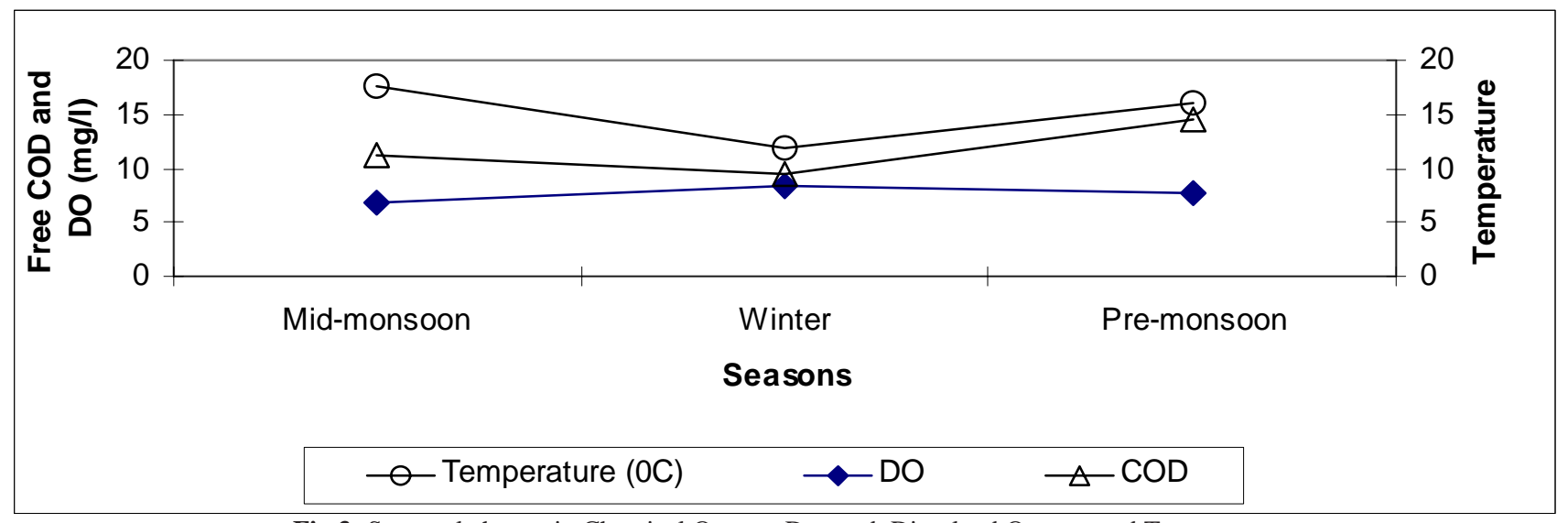

Fig 3: Seasonal change in Chemical Oxygen Demand, Dissolved Oxygen and Temperature

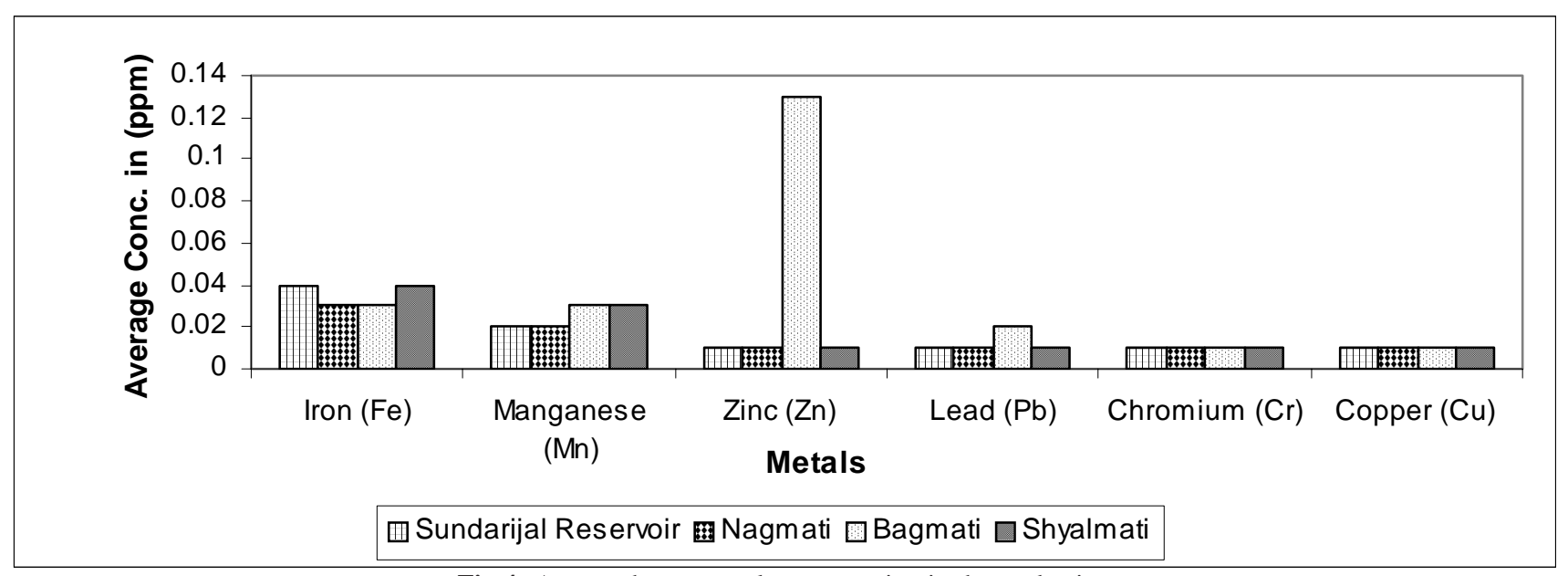

Fig 4: Average heavy metal concentration in the study sites

found within the European Commission (EC) standards (12$25^{\circ} \mathrm{C}$ ) set for the surface waters used for drinking purpose. The average $\mathrm{pH}$ was highest in mid-monsoon (7.48 \pm 0.09$)$ and lowest in winter (6.03 \pm 0.06$)$; they were within WHO (1991) and HMG/NBSM (2002) standard for drinking water (6.5-8.5). The slight seasonal fluctuation of $\mathrm{pH}$ can be attributed to the combined effect of temperature, dissolved $\mathrm{CO}_{2}$, liberation of ions and buffering capacity of water (Agrawal, 1999). The $\mathrm{pH}$ measured in present study (6.03-7.48) was in a similar range to previous reports for Sundarijal area (ENPHO 1997, Pokhrel 1997, Ghimire 1999, and Paudyal 2001), and Begnas and Rupa Tal (Lohman et al., 1988) (Fig. 2).

The TDS was highest in pre-monsoon and lowest in midmonsoon (Fig. 1). During hot and dry pre-monsoon relative amount of solutes could be high due to decrease in water volume in reservoir and streams. But during monsoon water is diluted due to heavy recharge in the form of direct precipitation and surface run off. The average TDS was highest in Bagmati and lowest in Nagmati. These values are far below the permissible level of drinking water standards of WHO (1000 mg/l) and EC (1500 mg/l). The conductivity was highest $(19.82 \mu \mathrm{s} / \mathrm{cm})$ in mid-monsoon and lowest $(15.16 \mathrm{~s} / \mathrm{cm})$ in winter (Fig. 1). A higher conductivity indicates the presence of higher amount of dissolved salts as well as plant nutrients in the water. The highest conductivity during the rainy season can be attributed to the liberation of ions from decomposed plant debris and flow of ions with surface run off from catchments to the water bodies. The lowest conductivity in winter may be due to cold environment and low input of ions from the catchments area. Water conductivity measured in our study area was lower than in pristine stream that normally ranged from 35 to $60 \mu \mathrm{s} / \mathrm{cm}$ (ENPHO, 1997). The values found in present study were far below the threshold limit of EC standards for drinking water ( $400 \mu \mathrm{s} / \mathrm{cm})$. The conductivity measured in present study were similar to the previous report for the same area (ENPHO 1996, 1997, Ghimire 1999 and Paudyal 2001), but lower than the values recorded by Pokhrel (1997) in Sundarijal area. TDS and conductivity showed opposite pattern of seasonal change (Fig. 1). When TDS is high conductivity is also expected to be high. But in our measurement when TDS was highest during pre-monsoon conductivity was comparatively low. It could be possible because all dissolved substances may not ionize and do not raise conductivity as expected.

The alkalinity was mainly due to bicarbonates whereas the carbonates were not in predictable amount because there would be practically no carbonates in water with $\mathrm{pH}$ from 4.5 to 8.3 (Jhingran, 1975). The average alkalinity was measured highest in winter $(44.5 \pm 3.8 \mathrm{mg} / \mathrm{l})$ and lowest in pre-monsoon (16.6 $\pm 1.25 \mathrm{mg} / \mathrm{l})$ (Fig. 2). The highest alkalinity in winter might 


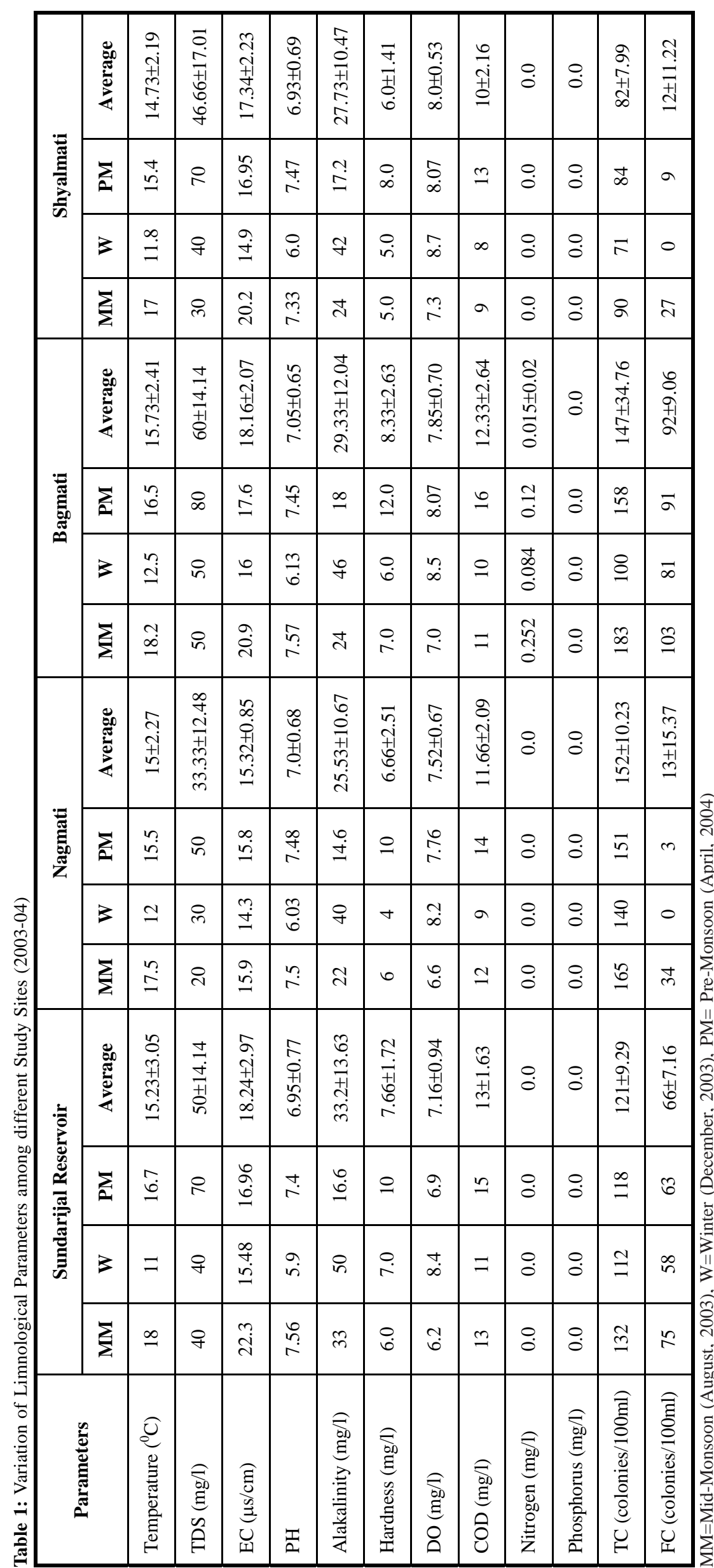

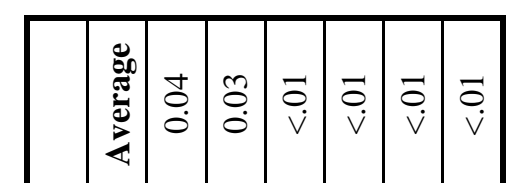

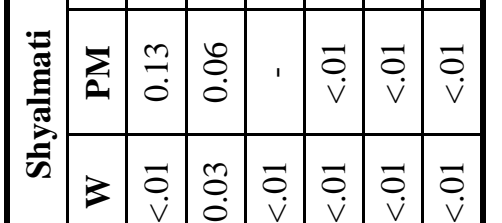

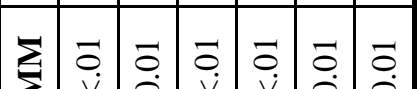

\begin{tabular}{lll|l|l|l|l|}
$\sum$ & 0 & 0 & 0 & 0 & 0 & 0 \\
$v$ & 0 & $\dot{v}$ & $\dot{v}$ & $\stackrel{0}{0}$ & $\stackrel{0}{0}$ \\
\hline
\end{tabular}

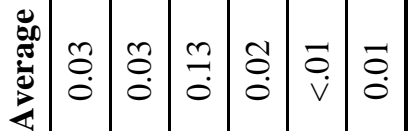

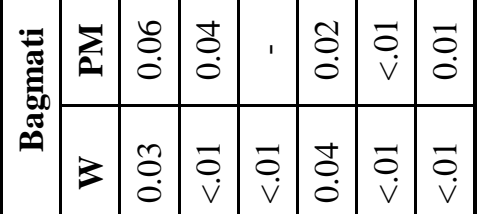

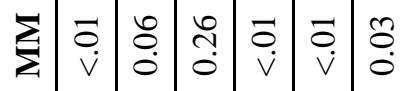

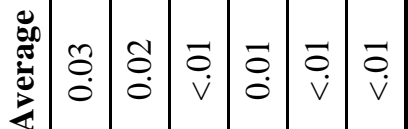

南

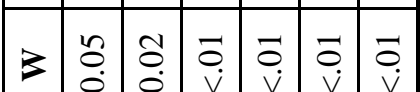

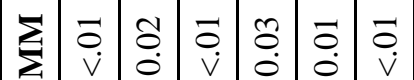

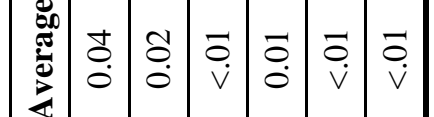

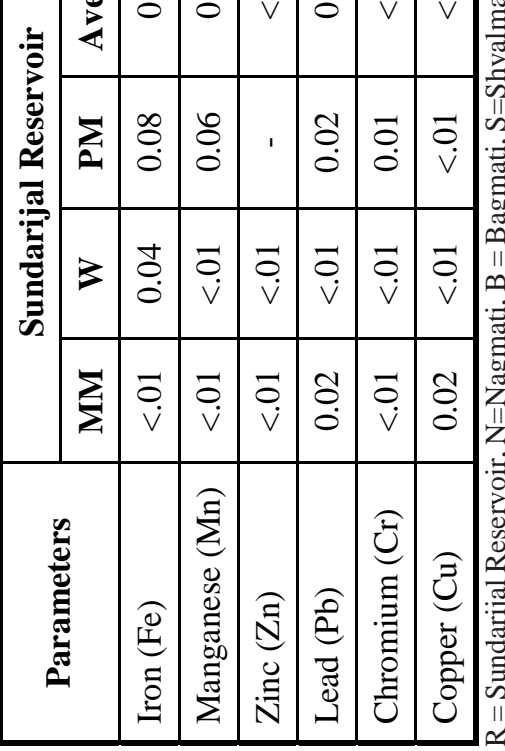

Scientific World, Vol. 6, No. 6, J uly 2008 
Table 3: Risk concepts and Faecal Coliform grading

\begin{tabular}{|l|l|l|}
\hline Faecal coliform grading & Grade & Risk \\
\hline 0 & A & No risk \\
\hline $1-10$ & B & Low risk \\
\hline $11-100$ & C & High risk \\
\hline $101-1000$ & D & Very high risk \\
\hline
\end{tabular}

be due to less water volume and more bicarbonates ions than other seasons. Among the study sites, the highest total alkalinity was recorded in Sundarijal reservoir (33.2 $\pm 13.63 \mathrm{mg} / \mathrm{l})$ and lowest in Nagmati (25.53 $\pm 10.67 \mathrm{mg} / \mathrm{l})$. These values were similar to previous report for Sundarijal (Paudyal, 2001) and also within the range $(12.012-54.054 \mathrm{mg} / \mathrm{l})$ reported for Tinau River (Sharma and Shrestha, 2001). Hardness was highest in pre-monsoon $(10 \pm 1.41 \mathrm{mg} / \mathrm{l})$ and lowest in winter $(5.5 \pm 1.11 \mathrm{mg} /$ l) (Fig. 2). Input of $\mathrm{Ca}$ and $\mathrm{Mg}$ from mother rock by weathering under high temperature might have increased hardness during monsoon. High absorption of these ions by aquatic organisms during other seasons might have reduced water hardness. Similar trend was reported for Punyamati river (Dangol and Lacoul, 1996) as well as for Sundarijal (ENPHO 1997, Paudyal 2001). Water of these rivers and reservoir can be regarded as soft water (ENPHO, 1996) and the value was below the WHO standard of $500 \mathrm{mg} / \mathrm{l}$.

DO was lowest during mid monsoon $(6.7 \pm 0.41 \mathrm{mg} / \mathrm{l})$ and highest during winter $(8.42 \pm 0.14 \mathrm{mg} / \mathrm{l})$ (Fig. 3); this trend was opposite to the trend shown by temperature. When temperature increases gas solubility of water decreases and microbial activity increases; both these changes can reduce DO in water. The same trend was also reported for Beeshazaari lake (Burlakoti, 2003) and Gaindahawa lake (Simkhada, 2003). In the present study the average DO level varied from $7.16 \pm 0.24 \mathrm{mg} / \mathrm{l}$ in Sundarijal reservoir to $8.00 .13 \mathrm{mg} / \mathrm{l}$ in Shyalmati. A variation of DO level might be explained by a joint effect of temperature, photosynthesis, respiration, organic waste, aeration and sediment concentration (Budge and Verma, 1985). Chemical oxygen demand (COD) was highest in pre-monsoon $(14.5 \pm 1.11 \mathrm{mg} / \mathrm{l})$ and lowest in winter $(9.5 \pm 1.11 \mathrm{mg} / \mathrm{l})$. The highest COD in pre-monsoon may be due to high amount of domestic and agricultural wastes in the study sites from nearby settlement areas. Mid-monsoon value of COD could be lower than that of pre-monsoon because heavy rain and flooding of river in mid-monsoon wash off all the decaying organic matters and hence reduce COD (Mathur et al., 1991). The COD measured in the present study was lower than the value reported by Ghimire (1999) $(16 \mathrm{mg} / \mathrm{l}$ in December, 1998) but higher than to ENPHO (2003) (7 mg/l) for Sundarijal reservoir.

Very low level of total nitrogen was measured in Bagmati (0.084 $\mathrm{mg} / \mathrm{l}$ in winter and $0.252 \mathrm{mg} / \mathrm{l}$ in mid-monsoon) (Table 1); it was not detected in water samples from other study sites. However, Ghimire (1999) measured 0.7 mg/l organic nitrogen in Sundarijal. The Sundarijal reservoir can be considered as ultra-oligotrophic (Wetzel, 1983). Phosphorus was not found in detectable amount in all the sites in all the seasons. The run off water could carry phosphorous from forest and agricultural land but in small amount, and further diluted in streams and reservoir to the level not detectable by the chemical method we used. However previous works reported phosphorus from the reservoir in small amount: 0.04-0.12 mg/l by ENPHO (1997) and $0.03 \mathrm{mg} / \mathrm{l}$ of orthophosphate by Paudyal (2001). Thus N and $\mathrm{P}$ content of the reservoir could not support the growth of macrophytes; only some microphytes and diatoms were collected during present study.

Heavy metal concentration in the study sites were above the natural level for streams as given by Whitton and Say (1975). $\mathrm{Cu}$ and $\mathrm{Zn}$ could be derived from chemical fertilizers and pesticides (Ali et al., 1992) used in agricultural land of the catchments; Cr from the animal wastes (Best, 1982) and $\mathrm{Pb}$ from vehicular emission or bullet firing by security personnel. $\mathrm{Pb}$ emission from vehicles causes a distinct increase of lead content in the soil (Brady, 1995). The metals though being in trace amount, their slight increase can be a useful parameter for evaluation of water pollution and its load and trend in the river. In the present study, concentrations of most of the selected heavy metals were highest in pre-monsoon and lowest in winter. But concentration of Fe was lowest in mid-monsoon while $\mathrm{Cu}$ was highest in the same season. Among the study sites, heavy metal concentration in general was highest in Bagmati in all seasons; it indicates that Bagmati was contaminated by heavy metals more than the other streams (Table 2). Heavy metals concentration were below the threshold limit of WHO (1991) and HMG/NBSM (2002) except for lead in all the seasons. All these values were similar to Paudyal (2001) in Sundarijal reservoir. Fe and Mn concentrations were similar to report of Yadav et al. (1984) in the same sites, but these two metals were not found in detectable amount in Madrikhola, Bhotekhola and Amalabisauni reservoir of Pokhara (Shrestha et al., 1991). Heavy metal contamination due to natural and anthropogenic sources is a global environmental concern which poses a significant threat to public health because of its persistence, biomagnifications and accumulation in food chain (Rajendran et al., 2003).

\section{Bacterial contamination}

Average total coliform (TC) and faecal coliform (FC) counts were highest in mid-monsoon followed by pre-monsoon and lowest in winter. In mid-monsoon, both TC and FC counts were highest (183/100ml and 103/100ml respectively) lowest in Shyalmati (90/100ml and 27/100ml respectively). The TC count was highest in Nagmati and lowest in Shyalmati but FC count was highest in Bagmati and lowest from Nagmati (Table 1). Higher FC counts in Bagmati may be due to sewage and faecal materials from catchment areas. The reservoir also had relatively high TC and FC level (Table 1). ENPHO (1996) also found FC densities 8 to 160 cell $/ 100 \mathrm{ml}$ in the water from streams and reservoir in Shivapuri area. The FC counts of our sites were slightly lesser than reported for Madrikhola, Bhotekhola and Amalabisauni reservoir in Pokhara (Shrestha et al. 1991). According to WHO (1991) coliform bacteria should not be detected in drinking water supplies and according to specification of drinking water distributed through pipeline distribution system, no samples should contain more than 10 coliforms per 100ml and no samples should contain faecal coliform organisms (HMG/NBSM, 2002). Based on FC count, WHO has classified water into four risk grades (Table 3) (as cited by 
ENPHO, 2001). According to this classification, all the water samples from the present study sites could be categorized as high-risk grade (Table 3). However, our sample size was not large enough to reach into final conclusion and these data should be considered as preliminary. These water sources were within the standard (TC-5000/ml and FC- 2000/ml, EC standard) for the raw water sources used for potable extraction after intense physical and chemical treatments with disinfectants.

\section{CONCLUSIONS}

Though the Sundarijal reservoir is the main source of water supply to Kathmandu metropolitan, watershed of the reservoir and its feeding streams were not properly managed. Open toilets in the residential area, free grazing even near the reservoir, uncontrolled use of reservoir premises for cleaning and recreation had deteriorated the surrounding environment and water quality of the reservoir and the feeding streams. Although the physical and chemical properties reported in this study were within the WHO standard for drinking water, presence of high coliform bacteria made it non potable before intense treatments with disinfectants.

\section{ACKNOWLEDGEMENTS}

For laboratory facilities, we express our sincere thanks to Central Department of Botany, TU, and Nepal Bureau of Standards and Metrology (NBSM), Balaju. We are thankful to Department of National Park and Wildlife Conservation (DNPWC), Babarmahal, Kathmandu for permission to conduct this research work in Sundarijal area of Shivapuri National Park, and local people of Mulkharka and Okhreni villages for providing information during questionnaire survey. The first author is thankful to Cornell-Nepal Study Program (CNSP), Tribhuvan University, for partial financial support to this work.

\section{REFERENCES}

Agrawal SC. 1999. Limnology. A.P.H. Publishing Corporation, New Delhi.

Ali EA, YH Ibrahim and MM Nasralla. 1992. Contamination of the agricultural land due to industrial activities south of greater Cairo. J. Environment Sci. health Part-A. Env. Sci. Enj. 27: 1293-1304.

Anonymous. 2004. Poor sanitation: the number one enemy of the world. A Newsletter, Lumanti Support Group for Shelter, Kupondole, Lalitpur. Pp 1.

APHA. 1992. Standard Methods for the Examination of Water and Waste Water (18 ${ }^{\text {th }}$ edition). American Public Health Association, Washington DC, USA.

Badge, U.S. and A.K. Verma. 1985. Limnological Studies on J.N.U. Lake, New Delhi, India. Bull. Bot. Soc. Sagar 32: 16-23.

Best EPH. 1982. Effects of water pollution on freshwater submerged macrophytes. In: C.K. Varshney (ed.), Water Pollution and Management Reviews. South Asian Publisher Pvt. Ltd. New Delhi, India.

Brady NC. 1995. The Nature and Properties of Soils. Printice-Hall of India, Pvt. Ltd. New Delhi.
Burlakoti C. 2003. Physico-chemical Characteristics and Macrophytes of Beeshazaari Lake, Chitwan. M.Sc. dissertation, Central Department of Botany, Tribhuvan University, Kathmandu, Nepal.

Dangol, N.S. and P. Lacoul. 1996. Growth and clump maintenance of Potamogeton crispus L. in Punyamati river, Panauti, Nepal. In: Jha, P.K., G.P.S. Ghimire, S.B. Karmacharya, S.R. Baral, and P. Lacoul, (eds.), Environment and Biodiversity: In the context of South Asia, 141-147. Ecological Society (ECOS), Kathmandu, Nepal.

DNPWC. 2003. Shivapuri National Park. A Brochure. Department of National Park and Wildlife Conservation, Babarmahal, Kathmandu.

ENPHO. 1996. Report on the Water Source Monitoring Program for the Shivapuri Watershed by Assessing Water Quality (First Phase). Environment and Public Health Organization, Kathmandu.

ENPHO. 1997. Monitoring and Assessment of Water quality in the Shivapuri Watershed. Environment and Public Health Organization, Kathmandu, Nepal.

ENPHO. 2001. A Diagnostic Survey Report on Drinking Water Quality Situation in the UNICEF's Project Area Kavre, Parsa and Chitwan. Environment and Public Health Organization, New Baneshwor, Kathmandu, Nepal. Pp 3

ENPHO. 2003. The South Asian Transboundary Water Quality Monitoring Programme. ENPHO Magazine, pp. 57-59. Environment and Public Health Organization, New Baneshwor, Kathmandu, Nepal.

FAO. 1979. Food and Nutrition Paper 14/4. Manuals of food quality control: Microbiological analysis. Food and Agriculture Organization (FAO) of the United Nations, Rome. Pp. D-34.

Ghimire S. 1999. Monitoring of Heavy-metals by Screening Common Aquatic Macrophytes of the Bagmati River. M.Sc. dissertation, Central Department of Botany, Tribhuvan University, Kathmandu.

Gupta PK. 2000. Methods in Environmental Analysis: Water, Soil and Air. Agrobios Publishers, Jodhpur, India.

HMG/NBSM. 2002. Drinking Water Distributed Through Pipeline Distribution System Specification: NS 432/059. Nepal Bureau of Standards and Metrology, Balaju, Kathmandu. Pp. 1-7

Jha PK and HD Lekhak. 1999. Environmental pollution in Nepal. In: Majupuria, T.C. and R.K Majupuria, (eds.) Nepal Nature's Paradise, (New edition) pp 466-481. M. Devi, Gwalior, India.

Jhingran VG. 1975. Fish and Fishery of India. Hindustan Publishing Company, India.

Joshi R, S Joshi, H Shrestha, M Joshi and T Karki. 2000. Microbial quality and chemical constituents of different brand of mineral water available in Kathmandu valley. Proceedings of Third National Conference on Science and Technology, March 8-11, 1999. Pp 638-643. Royal Nepal Academy of Science and Technology (RONAST). Khumaltar, Lalitpur.

Kundangar MRD, SG Sarwar and J Hussain. 1996. Zooplankton Population and nutrient dynamics of wetlands of Wular lake Kashmir, India. In: Jha, P.K., G.P.S. Ghimire, S.B. Karmacharya, S.R. Baral, and P. Lacoul, (eds.), Environment and Biodiversity: In context of South Asia, 128-134. Ecological Society (ECOS), Kathmandu, Nepal.

Lohmen, K. J.R. Jones, M.F. Knowlton, D.B. Swar, M.A. Pamperl and B.J. Brazos. 1988. Pre-and post-Monsoon limnological characteristics of Lakes in the Pokhara and Kathmandu valleys, Nepal. Verh. Int. Ver. Limnol. 23: 558-565.

Mather, K., R.K. Sharma, K.C. Nand and S. Sharma. 1991. Water quality assessment of the river Chambal over the stretch of National Chambale Sanctuary in Madhaya Pradesh, India. J. Eco l. 18(1): 1-4. 
Miller Jr GT. 2002. Living in the Environment. Wadsworth Publishing Co., California. 477 Pp.

Park K. 1994. Preventive and Social Medicine. M/S Banarsidas Bhanot Publishers, Jabalpur, India.

Paudyal PK. 2001. Study of Physico-chemical and Bacteriological Paratmers of Bagmati River and Treatment of Polluted water using Cladosporim resinae. M.Sc. dissertation, Central Department of Microbiology, Tribhuvan University, Kirtipur, Nepal.

Pokhrel AK. 1997. A Study of Interrelationships of Diatoms with Water Parameters in Sundarijal Pond and Reservoir. M.Sc. dissertation, Central Department of Botany, Tribhuvan University, Kathmandu.

Rajendran P, J Muthukrishnan and P Gunasekaran. 2003. Microbes in Heavy metal Remediation. Indian Journal of Experimental Biology 41(9) September: 935-944.

Saxena MM. 1989. Environmental Analysis: Water, Soil and Air. Agro Botanical Publishers, India.

Sharma CM and J Shrestha. 2001. Fish diversity and fishery resources of the Tinau river, Western Nepal. In: Jha, P.K., S.R. Baral, S.B. Karmacharya, H.D. Lekhak, P. Lacoul, and C.B. Baniya (eds.), Environment and Agriculture: Biodiversity, Agriculture and Pollution in South Asia, pp. 78-83. Ecological Society (ECOS), Kathmandu, Nepal.

Shrestha J. 2004. Overview on water quality of transboundary rivers of Nepal. ENPHO Magazine 2004. Environment and Public Health Organization, Kathmandu, Nepal.
Shrestha RR, M Shrestha and B Subba. 1991. Drinking Water of Pokhara: A case study. Environment and Public Health Organization (ENPHO), Kathmandu, Nepal.

Simkhada D. 2003. Ecology and Management Issues of Gaindahawa Lake, Rupendehi, Nepal. M.Sc. dissertation. Central Department of Botany, Tribhuvan Universisty, Kathmandu, Nepal.

UNESCO. 2003. Water for People Water for Life. The United Nations World Water Development Report. UNESCO and United Nations Water Assessment Program (WWAP), Berghahn.

UNICEF. 1997. Children and Women of Nepal: A Situation Analysis. United Nations Children's Fund, Kathmandu.

Wetzel RG. 1983. Limnology. Second edition. Saunders college Publishing, USA.

Whitton BA and PJ Say. 1975. Heavy metals. In: B.A. Whitton (ed.) River Ecology, pp 286-311. Blackwell Scientific Publication, London.

WHO. 1991. Guidelines for Drinking-water Quality, Vol: I, II and III. World Health Organization, Geneva.

WWF. 1998. Living Planet Report: Over Consumption in Driving the Rapid Decline of the World's Environments. World Wide Fund for Nature, Gland, Switzerland.

Yadav UR, D Joshi, RB Khadka, TB Karki and DN Sutihar. 1984. The Study of Shivapuri Water-shed Environment. HMG, National Council for Science and Technology, Kathmandu, Nepal. 